(昭和 36 年 5 月 24 日受理)

ボリプロピレン緎維の後処理

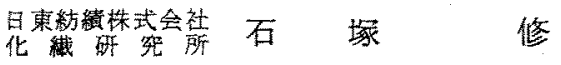

\title{
AFTER-TREATMENT OF POLYPROPYLENE FIBRE
}

\author{
By Osamu Ishizuka
}

(Research Laboratory, Nitto Boseki Co., Fukuyama-machi, Fukushima Prefecture, Japan)

The spun yarn may be drawn several times its original length. This drawing is the strengthforming structural change which adapts polypropylene to a wide range of utility in the textile field.

The drawing ratio has a considerable influence on the mechanical properties of fibres, and the maximum ratio is desirable. The maximum drawing ratio decreases moderately with increasing spinning draft, however the maximum drawing breaks the influence of spinning draft to mechanical properties of fibre, and gets to high Young's modulus of $600 \mathrm{~kg} / \mathrm{mm}^{2}$.

The thermal treatment carried out in $120 \sim 140^{\circ} \mathrm{C}$ for few minutes improves the thermal dimensional stability of fibres.

(Received May 24, 1961)

\section{1.緒要}

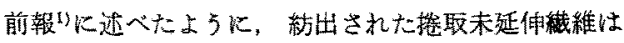
伸度が非常に大きく䒠用織維ではない。この点は继の合

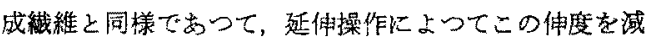
少せしめる。ぬた，この延伸操作によつて生じた練粠の

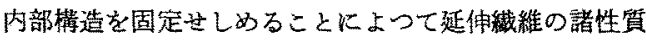

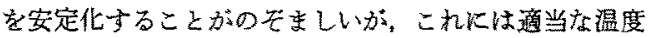
での熱始理が有效で㐫る。このことは一般の合成織維同 椂結晶性ポリプロピレン織維についてす成立するるのと 考它られる。

\section{2. 延伸}

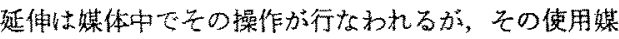

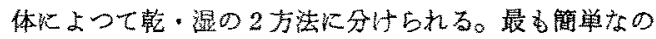
は箔温些気中で延伸する方法であるが，前報りに示した ように延伸に相当のエネルギーを要し，むた延伸速度を 小さくして低延伸倍率で行なかない限りクラックを生し

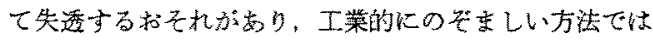

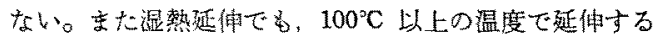

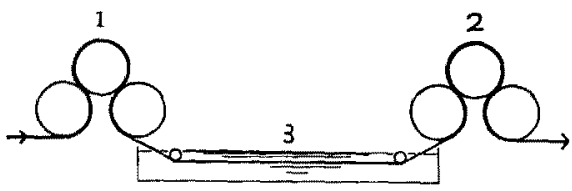

Fig 1. The drawing apparatus.
ためにはたとえばグリセリンなとの浴液を必要とし，延 伸速度を大にするとこ礼の浴外への運び出しが多くな

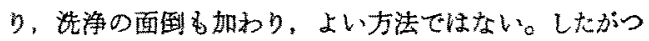
て, 実用性ある万法として, 熱水中延伸および熱面接触 加熱（空惨中）延伸を行なつたが，本報告には前者につ いて述へ五。

\section{1 湿熱延保法}

第1 図に略图を示士よ5に，2組のタローシーーローテ 1，2を用いて，2の方の表面速度家1のそれの10倍

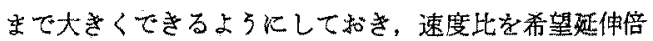
率に等しくする。この 2 組のクローメ゙ーローラの中間に 蓺水浴 3 娄特く。

\section{2 最高延伸倍率}

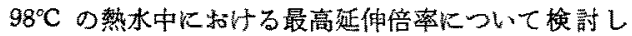
太。

\subsection{1 昍出量と最高延伸倍乘}

吐出量を $6.65 \mathrm{cc} / \mathrm{min}$ から $18.7 \mathrm{cc} / \mathrm{min}$ まで変化せし

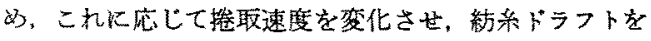

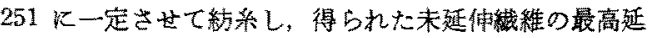

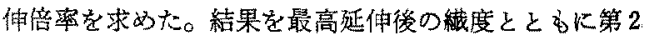
网红示要。

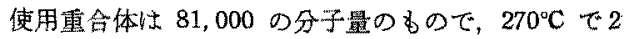
時間溶融して紡亲した。紡亲ドラフトが一定であれい゙昍 出量をする範明で変化しても撮高延伸率は变わらない。

\section{2 .2 溶触時間之最高延伸倍率}

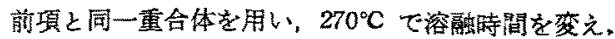




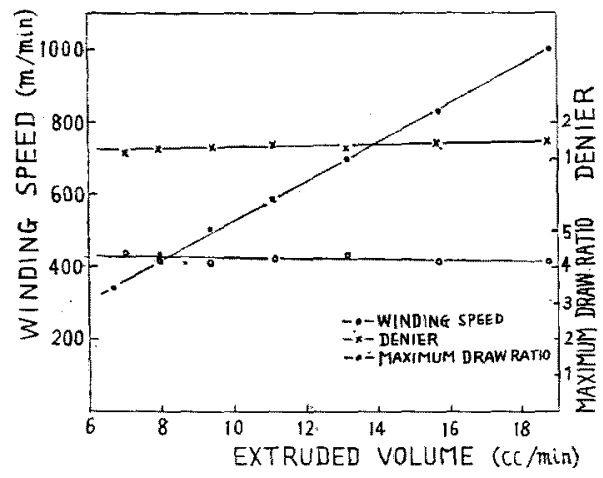

Fig 2. Extruded volume, winding speed-maximum draw ratio, and their denier relations (spin draft 250 constant).
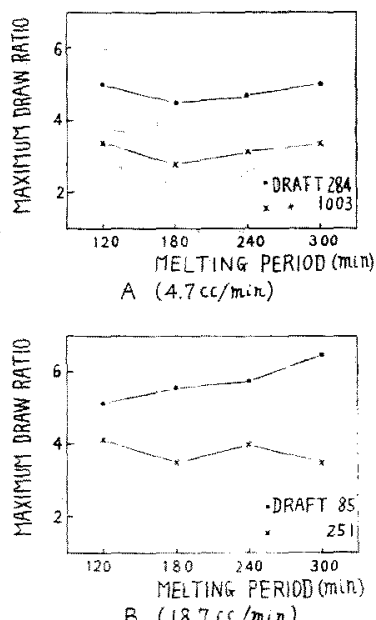

Fig 3. Relation of maximum draw ratio and melting period.

$4.7 \mathrm{cc} / \mathrm{min}$ および $18.7 \mathrm{cc} / \mathrm{min}$ の时出量で，それ杂れ 紡亲ドラフトを $1003 ， 284$ および 251，85 として絖禾 ドラフトの異なつた 4 種の末延伸織維を得だ。これらの 藏維 $98^{\circ} \mathrm{C}$ の熱木中に $10 \mathrm{~m} / \mathrm{min} の$ 速度で送り込み， 最高延伸倍率を求め各ドラフト場合について溶融時間 に対してプロットした結果を第 3 図A，Bに示す。

四中Aの紡系ドラフト 1003 と284 拈よびBの 251 の 場合の最高延伸倍率は溶融侍閒の影警はほとんど受けな いが，紡系ドラフト85の場合は溶融特間の稼過ととも に最高葀伸倍率が多少增大与る傎向が心る。

\section{2 .3 紡紟ドラフトと最高延伸倍率}

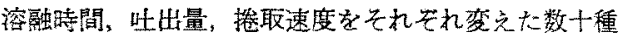

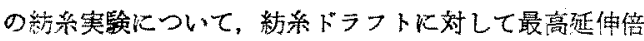

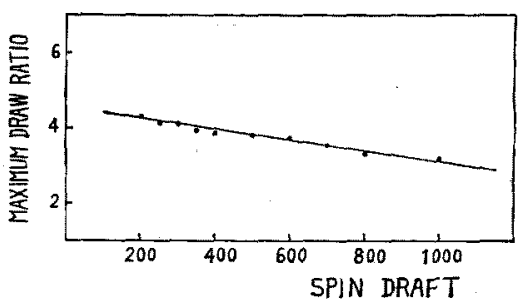

Fig 4. The Relation of maximum draw ratio and spin draft.

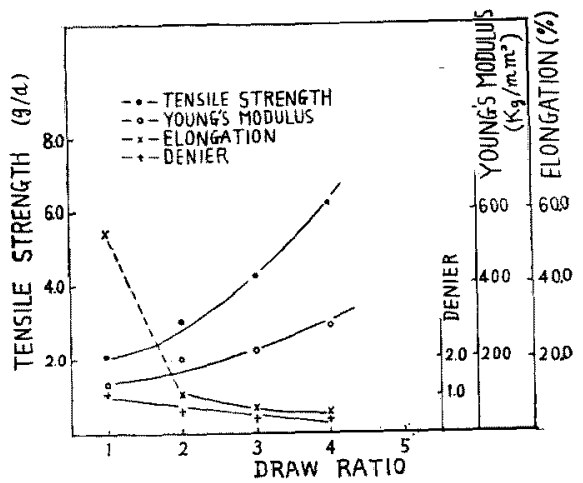

Fig 5. Relations of fibre properties and draw ratio $(15 \mathrm{~m} / \mathrm{min}$ feed $)$.

率をプロットすると第4図に示した結果が得られる。

紡采ドラフトの增大にともなつて最高延伸倍率は直線

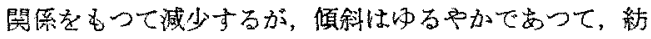
系で强くドラフトした割には最高延伸倍率は低下しない から細瀻度維を希望する場合には紡米ドラフトの方を 大きくすることが得策であるすなから，たと光ば紡亲 ドラフト 350 での紡系緎維は最高 4 倍の逨続题伸が可能 であり総ドラフトは1400にしかならないが，紡系ドラ フトを 1100 で紡系すれば最高 3 倍延伸が可能であるか ら綌ドラフト 3300 になり非常に細い絨維が紡糸できる。 この関係が焏度に大きい紡系ドラフトまで成立するとす れば，約 3000 の紡系ドラフトで紡系した䄉維は未延伸 の状体で，普通条件の延伸織維と同様の性質をるつこと る考光られる。

\section{3 延伸倍率之緎維性留}

分子量 49,000 の重台体を $270^{\circ} \mathrm{C} て ゙ 80$ 分間溶融し, $26.4 \mathrm{cc} / \mathrm{min}$ の吐出速度，紡条ドラフト110で紡系した 未远伸驖維を用いて，延伸後 $130^{\circ} \mathrm{C} て 120$ 分処理した

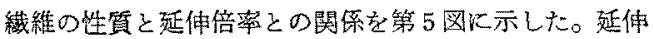

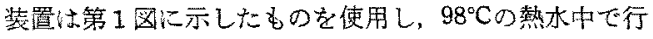
なつた。織維の延伸装睓への供給恃 $15 \mathrm{~m} / \mathrm{min}$ とした。 紻維の分子量怯 35,000 である。

正伸倍率の增大とともに強度およびヤング率は上男す 


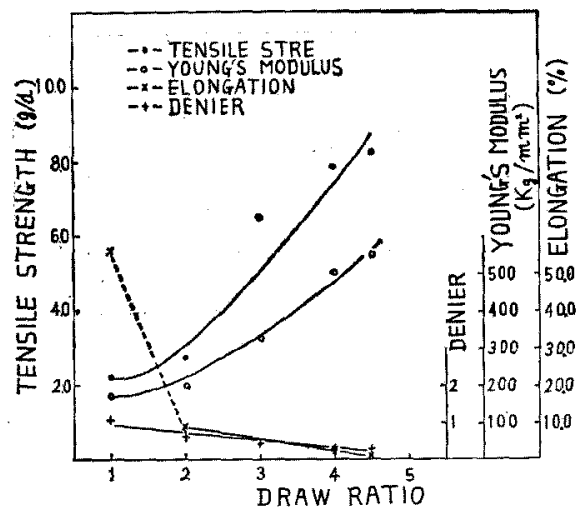

Fig 6. Relations of fibre properties and draw ratio $(10 \mathrm{~m} / \mathrm{min}$ feed).

る。同時に伸度は減少する。

供給速度を $10 \mathrm{~m} / \mathrm{min}$ 飞し立場合の結果を第 6 图江示 す。

緘維の供給速度 $15 \mathrm{~m} / \mathrm{min}$ の場合最高延伸倍率が 4.0 倍であるの対して $10 \mathrm{~m} / \mathrm{min}$ の場合は 4.5 倍まで上 界する。強度怙よびヤング率の高い法どのぞましく，ま

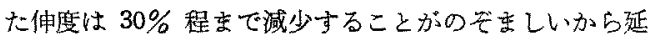
伸倍率恃最高が上く，乙たがつて延伸速度は小さいすが 効果がある。延伸条件を選べぱ $600 \mathrm{~kg} / \mathrm{mm}^{2}$ 程度のヤン グ率纪達する。

\section{3. 熱 処理}

延伸織維の内部構造を安定化し，延伸の効果を固定す るために熱処理が行なわれる。

\section{1 熱処理方法}

熱処理の方法としては延伸同様乾湿の二方法があり， さらに緊張下に行なら場合之無㪝張下に行なう場台之が ある。本報告に括いては延伸瀻維を加熱空気中で定長緊

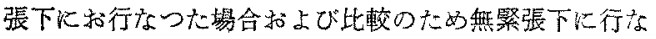
つた場合について述べる。

\section{2 熱処理亡強伸度}

\section{2 .1 末延伸䥫維}

未政伸䄉維はすで述べたよ5に非常に大きな伸度を すつので可及的に延伸してから熱处理を活どこすのが管

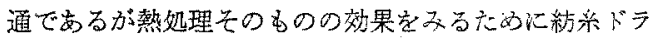
フト833の挖取未延伸瀻䋐を $130^{\circ} \mathrm{C} て ゙ 120$ 分処理した。 結果を第1表に示す。また，比較のたる同未延俄瀻維を 3.0 倍延伸後同一条件て熱起理を行站つた結果虽併載す る。

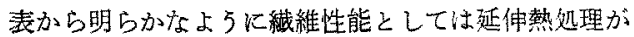
最る秀れているが，未征伸織維に対する熱処理効果も顕 著であり、この程度の性能があれば使用目的汇よつては
第1表 末延伸緖維に枋ける熱処理効果

\begin{tabular}{|c|c|c|c|c|c|}
\hline 処 理 名 & $\begin{array}{c}\text { 織度 } \\
\mathrm{d}\end{array}$ & 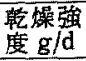 & $\begin{array}{l}\text { 䡎燥伸 } \\
\text { 度 \% }\end{array}$ & $\begin{array}{l}\text { 結節强 } \\
\text { 度 } \mathrm{g} / \mathrm{d}\end{array}$ & 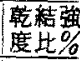 \\
\hline 未延 伸 棭 維 & 1.61 & 12 & 600 & - & - \\
\hline 未延伸熱処理械維 & 1.62 & 5.38 & 25.7 & 4.29 & 79.7 \\
\hline 延伸熱処理維 & 0.55 & 8.84 & 24.8 & 7.75 & 87,7 \\
\hline
\end{tabular}

第 2 表 惩伸瀻維の熱処理効果

\begin{tabular}{|c|c|c|c|c|c|c|}
\hline $\begin{array}{l}\text { 紡系 h } \\
\text { 今 } \\
\end{array}$ & 処 理 名 & $\begin{array}{c}\text { 瀻度 } \\
\mathrm{d}\end{array}$ & $\begin{array}{l}\text { 稓燥强 } \\
\text { 度 } \mathrm{g} / \mathrm{c}\end{array}$ & 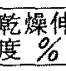 & $\begin{array}{l}\text { 絬節強 } \\
\text { 度 } \mathrm{g} / \mathrm{d}\end{array}$ & $\begin{array}{l}\text { 結强度 } \\
\qquad \% \% \\
\end{array}$ \\
\hline & 延伸絾 維 & 0.93 & 6.31 & 25.5 & 5.68 & 89.9 \\
\hline 502 & $\begin{array}{l}\text { 定長緊張 } \\
\text { 熱処理墄維 }\end{array}$ & 0.89 & 7.52 & 21.8 & 6.49 & 86.4 \\
\hline & 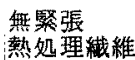 & 1.07 & 6.49 & 30.4 & 5.80 & 82.9 \\
\hline & 延伸䌦 維 & 0.65 & 7.49 & 24.4 & 7.32 & 97.9 \\
\hline 709 & 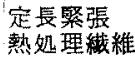 & 0.61 & 9.05 & 25.0 & 7.93 & 87.7 \\
\hline & 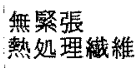 & 0.74 & 6,23 & 37.5 & 6.74 & 100 \\
\hline & 莚伸䌜維 & 0.51 & 6.90 & 23.8 & 6.39 & 100 \\
\hline 1003 & 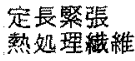 & 0.49 & 6.92 & 18.9 & 6.92 & 100 \\
\hline & 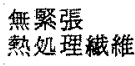 & 0.55 & 6.84 & 38.3 & 6.07 & 88.8 \\
\hline
\end{tabular}

他の合成瀻瀻に劣らない有用性意持つ。

\section{2 .2 延体䋞維}

紡系ドラフトを $502 ， 709 ， 1003$ として紡糸した緎維 をそれぞれ $3.5 ， 3.2 ， 3.3$ 倍に延伸した後，定長緊張下 に，または無緊張に $130^{\circ} \mathrm{C} て 120$ 分熱処理した結果を第 2 表以西方。

(1) 定長雾張処理

聚張下の熱処理では絨度は無論変わりなく，伸度は若 干低下して，強度は乾燥，結節ともに增加する。

(2) 無慗張処理

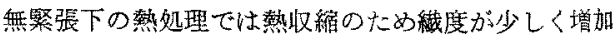
し，したがつて伸度は增大し，強度は㖕・結とも熱处理

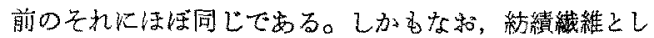
て充分の性能的つているから装置乱よび操作の䉍易性 から考筃に值するお法である。

\section{3 熱姏理織維の耐熱性}

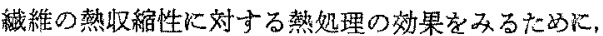
票ず，紡系ドラフト250で紡系し，倍率 3.8 倍で延伸し た㵶維を $100^{\circ} \mathrm{C}, 120^{\circ} \mathrm{C}, 130^{\circ} \mathrm{C}, 140^{\circ} \mathrm{C}$ の空気浴中に 10

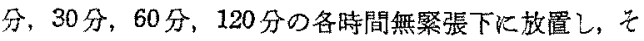
の収縮率を測定した。結果を第 7 図に示す。

七れぞれの盜度に叔いては 10 分以上時間を経過して

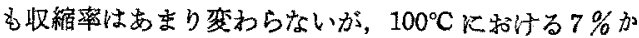
ら $140^{\circ} \mathrm{C}$ に特ける 16〜18\% まで高温任ど收縮率は大き 


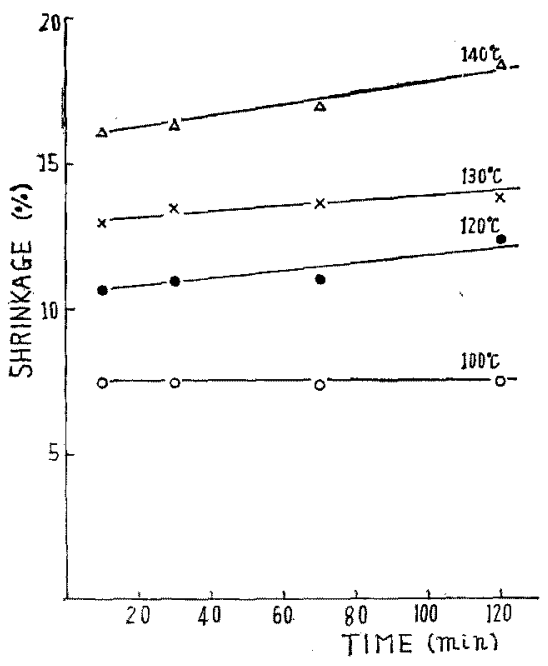

Fig 7.

Thermal dimensional stability of drawn fibre.

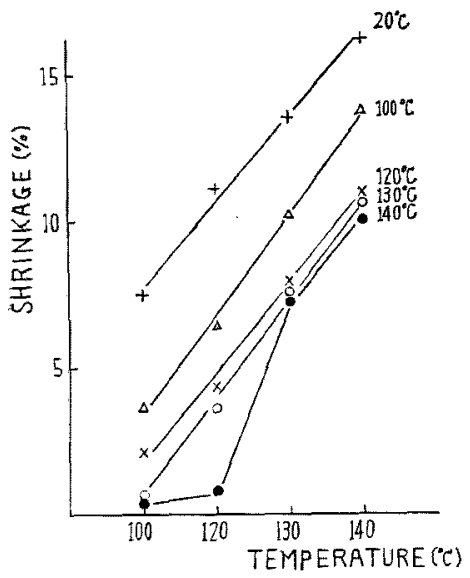

Fig 8 .

Thermal dimensional stability of heat set fibre.

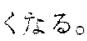

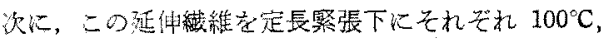
$120^{\circ} \mathrm{C}, 130 \mathrm{C}, 140^{\circ} \mathrm{C}$ て各 30 分間空気浴熱処理を行な 小得与月た瀻維の $100^{\circ} \mathrm{C}, 120^{\circ} \mathrm{C}, 130^{\circ} \mathrm{C}, 140^{\circ} \mathrm{C}$ 儿出 村る 30 分間無緊張下での熱収縮率を測定した結果を末 熱処理の場合（図に和いて $20^{\circ} \mathrm{C}$ の場合）とともに第8 图行示示。

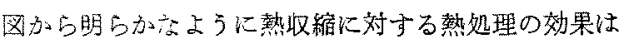
大きく，高温処理ほぞ䋊維の酎熱安定性はよくなる。

\section{4 処理時間}

こ机まで熱処理時間は120分を主としてきたが，緎維 束の比較的細い場合には短時閒処理が考えられ，特に連

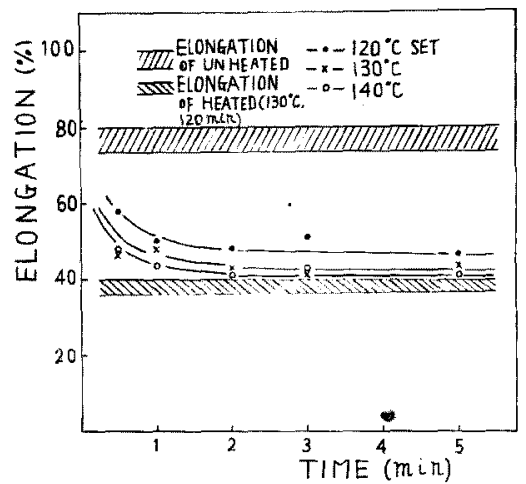

Fig 9. Effects of heating period.

続処理を行なうときはその方がのでしい。短時間内 での熱処理時間の効果をみるために特に伸度の大きい延 伸紻維を調製した。紡系ドラフトを 213 とて紡系し， 倍率 3.0 で延伸した。この末延伸絾維の最高延伸倍率は 4.2倍程度でるから 3.0 倍で延伸したるのは73 80\% の大きい伸度をるつ，これを熱処理すると伸度が減少す るが, 処理前の伸度が大きいだけに伸度の変化が大きく， 熱好理の効果をみるのに便利で岕る実験は絾維が所定 の処理温度に速か火達するようとグリセりン浴を用い， $120^{\circ} \mathrm{C} ， 130^{\circ} \mathrm{C}, 140^{\circ} \mathrm{C}$ に和いて $0.5 \sim 5$ 分間の籍囲内の 各時間漫せき処理して行なつた。結果を第 9 図に示す。 $140^{\circ} \mathrm{C}$ 処理では 5 分間の経過後には $130^{\circ} \mathrm{C} ， 120$ 分の

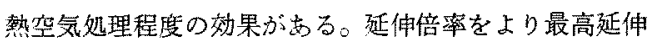
倍率に近ずけ伸度のより少ない延伸緎維を調製し，140 ${ }^{\circ} \mathrm{C}$ で数分間処理すれば充分の処理効果の発現を期待で ₹。

4. 絰括

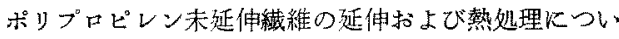
て倹討し, 次の結果を得た。

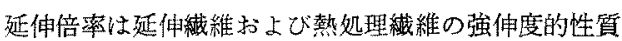

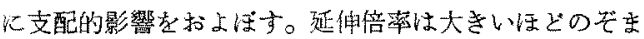

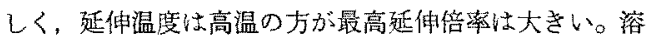

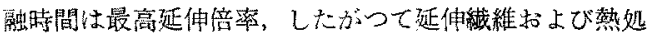

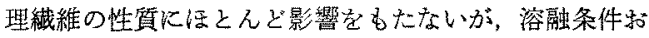
よび延伸条件定にすれば，最高延伸倍率は紡系ドラ フトに直線的に依存し，結糸ドラフトの增大にともなつ てゆるやかに減少する。紡糸ドラフトによる瀻維性質の 差異は最高延伸後消失し延伸条件によつてヤング率は $600 \mathrm{~kg} / \mathrm{mm}^{2}$ 火详高る。

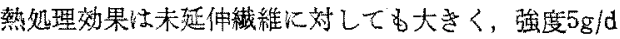
以上，伸度 $25 \sim 30 \%$ の䋐維が得られる。しかし，延伸

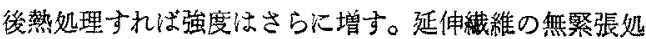


理では熱收縮をともならので相応の強度低下があるが， な拈 6〜7 $\mathrm{g} / \mathrm{d}$ の強度を示す。熱処理時間は処理量に上 るが緎維の温度を処理温度に達せしめてから，135〜140 ${ }^{\circ} \mathrm{C}$ で, 5 分程度でよい。

\section{文献}

1) 石坏；織学誌，投稿中

本研究は日化第 14 年会で講演した。本研究の遂行に あたり卸指導を賜つた京大倜尾先生に感謝します。また 終始御鞭撻家頂いた日東紡緢化䋐研究所長高浜博士に感 謝します。

(昭和 36 年 5 月 24 日受理日)

\title{
ポリプロピレン繊維製造工程の X 線的考察
}

日果紡續株式会社 石塚修
化絾研突所

\section{X-RAY STUDY IN MANUFACTURING OF POLYPROPYLENE FIBRE}

\author{
By Osamu Ishizuka
}

(Research Laboratory, Nitto Boseki Co., Fukuyama-machi, Fukushima Prefecture, Japan)

The behavior of polypropylene in the manufacturing processes for melt spinning was studied by means of $\mathrm{X}$-ray diffractions.

The results thus obtained are as follow:

(1) The melted polymer may crystallize in a monoclinic unit cell by a slow cooling, while in a pseudo-hexagonal by a rapid cooling.

(2) The diffraction patterns of the fibres which are spun from molten polymer are influenced by melting period, that is, in case of melting period within a certain hour, monoclinic pattern is shown, but of melting period over it, pseudo-hexagonal is obtained. This is explained by the lower crystallization rate based on molecular degradation.

(3) Molecular orientation decreases by increasing the time for which the polymer is held molten. while the other conditions are fixed. This decrease is apparently caused by decreasing the molecular entanglement owing to thermal degradation.

(4) After drawing of the quenched unoriented fibre, the oriented psiudo-hexagonal X-ray diagram is obtained, while in annealed oriented fibre, a diagram in which oriented pseudo-hexagonal pattern overlups on oriented monoclinic is obtained.

(5) The molecular configuration of undrawn fibre consists of two forms. That is the one is the molecular configuration in which a molecular axis is parallel to the fibre axis, the other the folding molecular configuration in which a molecular axis is perpendicular to the fibre axis Then by drawing accompanied by necking the later breaks up and rearranges to the former, and $\mathrm{X}$-ray diagram becomes pseudo-hexagonal.

(6) This pseudo-hexagonal packing of drawn fibre changes easily into monoclinic lattice by heating at $120^{\circ} \mathrm{C}$ or over.

(Received May 24, 1961)

\section{1. 緒㢇}

結晶性ポりプロピレンは結晶化速度歹結晶化度も大き

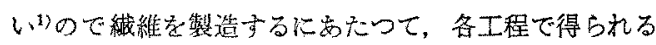

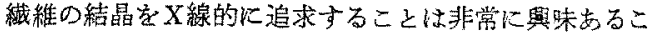
とである。このことはれた各工程の意義を探ることにも なり，製造条件の邀否を判定し，適当心織維製造条件を 導き出すことにるなる。 